\title{
Rare Earth Elements in the hydrothermal system at Okinawa Trough back-arc basin
}

\author{
Yayoi Hongo, ${ }^{1,4 *}$ HaJime Obata, ${ }^{1}$ ToshitaKa Gamo, ${ }^{1}$ Miwako NAKASEAma, ${ }^{2}$ Junichiro Ishibashi, ${ }^{2}$ \\ Uta Konno, ${ }^{3}$ Shunsuke SaEgusa, ${ }^{3}$ Satoru OHKubo ${ }^{3}$ and Urumu Tsunogai ${ }^{3}$ \\ ${ }^{1}$ Ocean Research Institute, The University of Tokyo, Japan \\ ${ }^{2}$ Department of Earth and Planetary Sciences, Kyushu University, Japan \\ ${ }^{3}$ Division of Earth and Planetary Sciences, Hokkaido University, Japan \\ ${ }^{4}$ RIKEN, The Institute of Physical and Chemical Research, Japan
}

(Received July 22, 2005; Accepted September 19, 2006)

\begin{abstract}
We present novel data sets of rare earth element (REE) distributions in a hydrothermal vent field at Yonaguni Knoll IV in the Okinawa Trough. Vertical REE profiles in three water columns showed horizontal variation of REE concentrations within 1000-1200 m. Hydrothermal plumes were discovered by anomalous values of methane, manganese and transmissometry at that site. Europium anomalies in the North Pacific deep water (NPDW) (Nozaki et al., 1999) normalized pattern decreased with distance from the hydrothermal vent site, indicating that the dilution of hydrothermal fluid in the plume can be traced using REE. The horizontal variation of negative Ce-anomalies represents the continuous scavenging of REE by suspended matter in the plume. In addition, we measured nine hydrothermal fluid samples. The REE geochemistry of hydrothermal vent systems had been investigated intensively at sediment-starved mid-oceanic ridges, but few studies had examined sediment-hosted hydrothermal systems like those of the Okinawa Trough. The chondrite-normalized REE patterns of the fluids collected at Yonaguni Knoll IV show typical lighter rare earth elements (LREE) and Eu enrichment similar to at the Mid-ocean Ridge sites. A remarkable characteristic of the Yonaguni Knoll IV fluid pattern is its higher concentrations of heavier rare earth elements (HREE) and La composition than the hydrothermal fluids of the sediment-starved East Pacific Rise and Trans-Atlantic Geotraverse. Such a feature is explainable by influences of covering sediments in the back-arc basin Okinawa Trough. At the hydrothermal vent, lighter REE (LREE) in the fluid was reduced systematically during fluid mixing with seawater within the chimney. Light REE elimination resembles fractionation caused by particle scavenging within the water column. However, the lack of Ce depletion, which is a typical REE feature in the water column, along with distinctive Eu reduction, were unique in the Yonaguni Knoll IV fluid, suggesting that fluid REE fractionation at the vent site was induced predominantly by coprecipitation with hydrothermally originated minerals (e.g. sulfate and carbonate), not by adhesive removal by $\mathrm{Fe}$ and/or Mn oxide particles. Previous studies had shown that REE removal and fractionation of the hydrothermal system were observed only in deposit samples. Results of this study elucidated REE fractionation in fluid samples using previous analytical data. We were also able to distinguish REE removal mechanisms occurring at the vent site and water column using REE pattern characteristics.
\end{abstract}

Keywords: Okinawa Trough, sediment-hosted hydrothermal activity, rare earth elements, hydrothermal fluid, hydrothermal plume

\section{INTRODUCTION}

This study elucidated rare earth element (REE: yttrium and all lanthanides) distributions in three water columns near a hydrothermal vent field in a typical sedimenthosted hydrothermal area of the southwestern point of the Okinawa Trough: Yonaguni Knoll IV. At that study

\footnotetext{
*Corresponding author (e-mail: yayoi@ riken.jp)

* Present address: RIKEN, The Institute of Physical and Chemical Research, Advanced Development and Supporting Center, Molecular Characterization Team, 2-1, Hirosawa, Wako, Saitama 351-0198, Japan.

Copyright $@ 2007$ by The Geochemical Society of Japan.
}

site, expansion of the hydrothermal plume had been observed using the manganese distribution (Doi et al., 2004) and light transmission anomalies. The use of REE presents great advantages for seawater characterization over using dissolved oxygen, salinity, and single trace elements by its single use: high-precision REE data are more sensitive than other proxies because of their great dynamic range of concentrations in seawater. In addition, their unique REE pattern provides information related to the elemental source and redox environment (Byrne and Sholkovits, 1996; Nozaki, 2001; Nozaki and Alibo, 2003). Especially in the hydrothermal area, REE is a useful tool to find muddy plumes because of its sensitive particle affinity and systematics. 
(a)

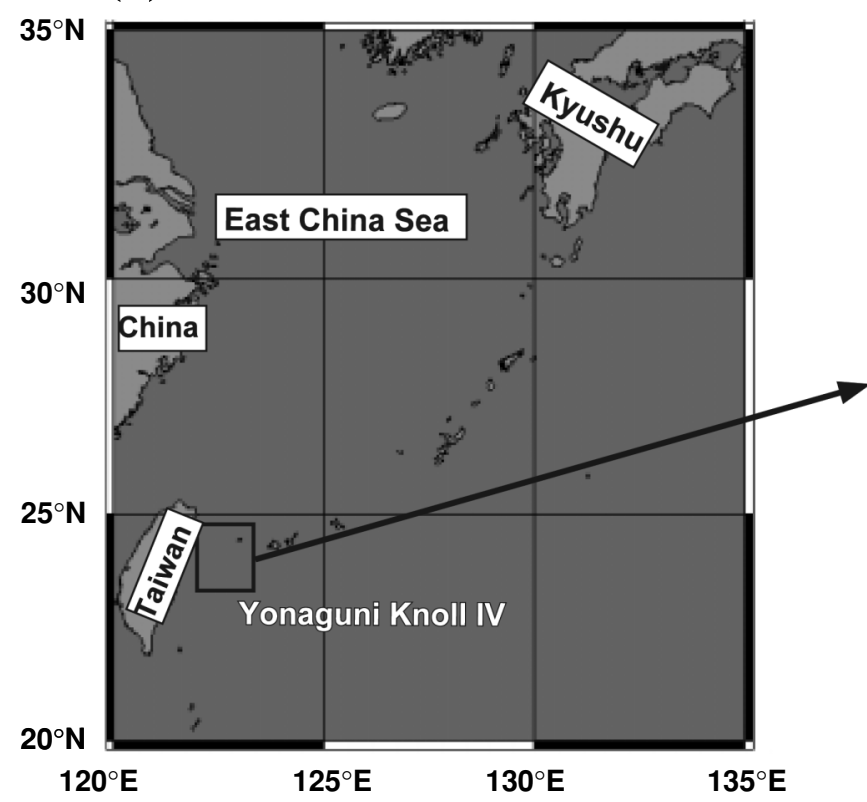

(b)

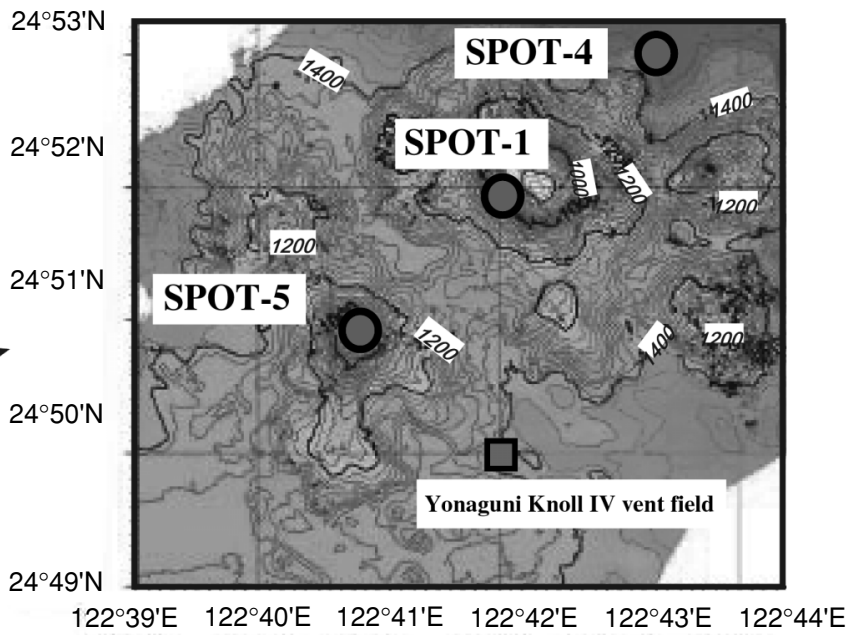

Fig. 1. a) Sampling locations in the Okinawa Trough. b) Vertical sampling and hydrothermal vent site at the Yonaguni Knoll IV. Latitudes and longitudes of the sampling stations are shown respectively in Tables 1 and 2.

To assess the contribution of hydrothermal activity to the surrounding REE distribution in seawater, we first describe the fluid REE character in the sediment-hosted hydrothermal system at Okinawa Trough, Yonaguni Knoll IV. Using solvent extraction followed by inductively coupled plasma mass spectrometry (ICP-MS), we can measure all REE with high precision (0.6-2.5\% for REEs, except $9.5 \%$ for $\mathrm{Ce}(\mathrm{III})$ ). All REE data, including those of single isotope elements, enable us to describe the complete chondrite-normalized patterns and to describe REE fractionations in detail.

Combining REE data in a hydrothermal fluid with that in the water column, we elucidated local mechanisms that influence the REE distribution in seawater. Variation of REE patterns from fluid to seawater occurred not only by particle scavenging in the water column (reviewed in Byrne and Sholkovits, 1996; Nozaki, 2001) but also by REE fractionation during precipitation from the hydrothermal fluid (Mitra et al., 1994; Mills and Elderfield, 1995). Typical features of hydrothermal REE systems have been studied mainly at the sediment-starved MidOcean Ridge, but a few investigations have examined the sediment-host back arc basin. Previous works have reported familiar characteristics of REE in hydrothermal fluids. Those characteristics reflect interactions between the hot fluids and volcanic rocks, and light-REE (La-Gd) enrichment with positive Eu-anomaly in chondrite-normalized REE patterns at the Mid-Atlantic Ridge
(Klinkhammer et al., 1994a; Campbell et al., 1988; Mitra et al., 1994) and East Pacific Rise (Douville et al., 1999). From the perspective of hydrothermal geochemistry, our interest is whether fluid REE compositions in the sediment-hosted system at the Okinawa Trough differ from those in the sediment-starved site. Hydrothermal fluids of sediment-hosted sites are known to be rich in $\mathrm{CO}_{2}$, $\mathrm{CH}_{4}$, and $\mathrm{NH}_{4}^{+}$, and to have higher alkalinity than those from sediment-starved sites because of the degradation of organic matter in the covering sediment, as observed in the Guaymas Basin of the Gulf of California (Von Damm et al., 1985), Escanaba Trough on the Gorda Ridge (James and Palmer, 2000) and Middle Valley on the Juan de Fuca Ridge (Butterfield et al., 1990), as well as in the Okinawa Trough (Sakai et al., 1990; Gamo et al., 1990, 1991). Chemical characteristics of hydrothermal fluid collected at the Okinawa Trough reveal higher concentrations of $\mathrm{K}$ and $\mathrm{Li}$ compared to any other reported site; it also has relatively lower Ca concentration (Sakai et al., 1990). We present characteristics of REE in the fluid here.

\section{SAMPLES AND METHODS}

Figure 1a) shows the Okinawa Trough study area. Vertical seawater samples in the Yonaguni Knoll IV were collected at SPOT-1, SPOT-4, and SPOT-5 (Fig. 1b)) using a CTD-carousel multi-sampling system with a transmissometer (25-cm light path; Sea Tech Inc.) during 


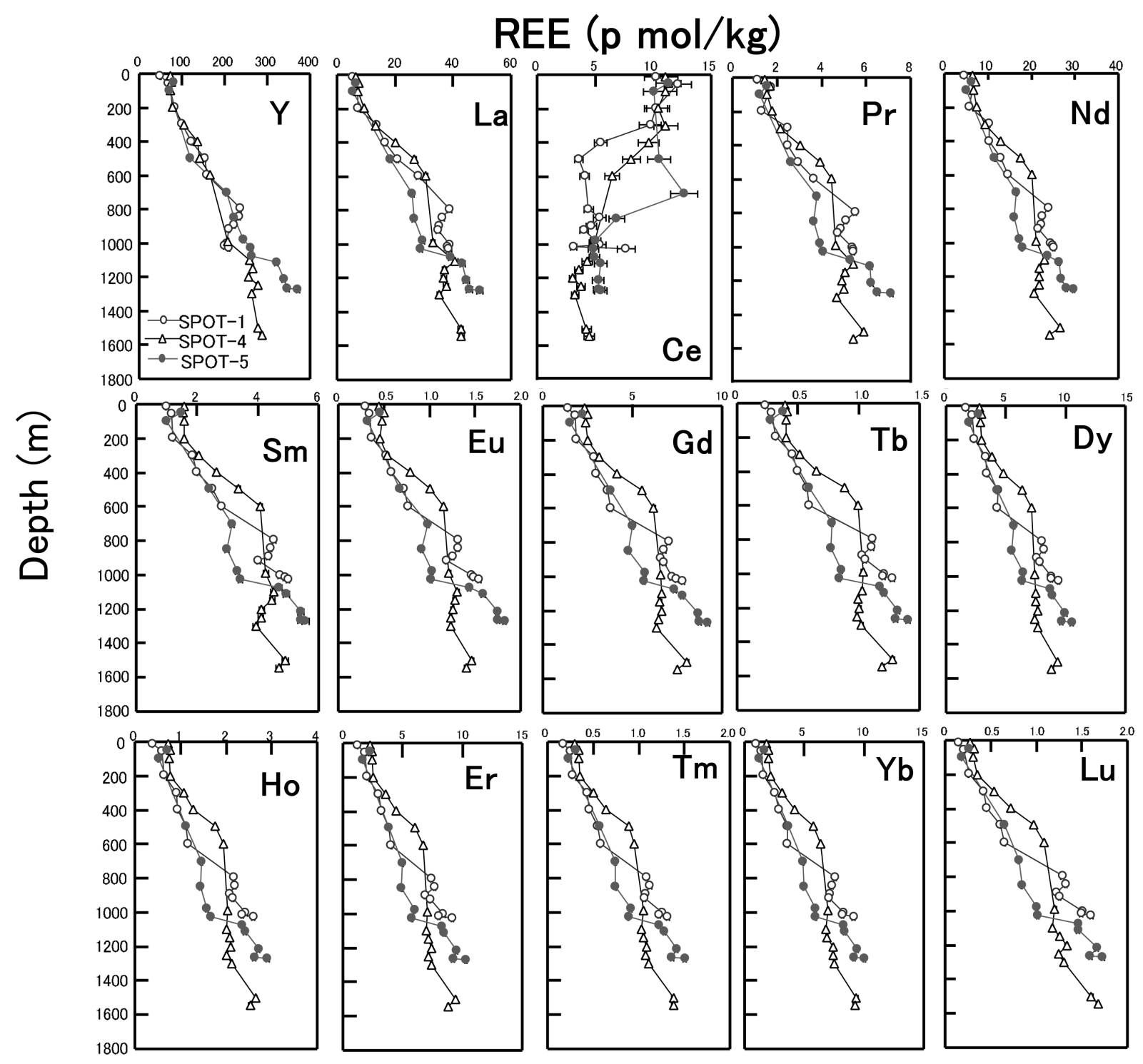

Fig. 2. REE vertical profiles at three SPOT stations: open circles - SPOT-1; open triangles - SPOT-4; closed circles - SPOT-5.

the $R / V$ Hakuho-maru (Ocean Research Institute, the University of Tokyo) KH-02-1 cruise (11 June, Naha-24 June, Tokyo, 2002). The above CTD-CMS system, attached at the end of a titanium reinforced cable $(8 \mathrm{~mm}$ o.d.) and a CTD deck unit (Model 11 plus; Sea-Bird Electronics, Inc.). The array frame (Carousel) can hold 24 water samplers (12L volume each).

Immediately after sampling, vertical seawater samples were filtered using a polycarbonate filter (pore size 0.2 $\mu \mathrm{m})$ in a built-in clean room on the ship. They were then acidified to less than $\mathrm{pH} 2$ using ultra-pure $\mathrm{HCl}$ (Tamapure-AA-; Tama Chemicals Co. Ltd.).

Hydrothermal vent fluid samples were collected during geomicrobiological and geochemical investigations of deep-sea hydrothermal vents in Yonaguni Knoll IV (M/
S Yokosuka, YK-04-05, Leg 2; 1 May, Komatsujima-16 May, Naha, 2004). All hydrothermal fluids were collected using a water-hydrothermal atsuryoku tight sampler (WHATS), which was developed for collecting fluid samples while maintaining gas pressure (Tsunogai et al., 2003), installed at the center of the manned submersible SHINKAI 6500 (JAMSTEC) during Dive815-Dive821. Fluid samples were collected at three chimney vents: Lion Chimney, Tiger Chimney (black smoker), and Mosquito Chimney $\left(162^{\circ} \mathrm{C}\right)$ at the Yonaguni Knoll IV hydrothermal site. The temperature probe contained five temperature measuring points in its $473-\mathrm{mm}$-long probe, in addition to a two-component ( $\mathrm{X}$ and $\mathrm{Y}$ ) tilt sensor and one temperature measuring point at the top of its data logger. Unfortunately, temperature data were not measured for 
all samples because of communication trouble with the $\mathrm{PC}$ and recording trouble at some dive samplings during expeditions. Shipboard analyses of hydrothermal fluid $\mathrm{pH}$ were performed using a Corning $\mathrm{pH}$ meter with a combined glass electrode, which was calibrated against standard solutions of $\mathrm{pH}=6.86\left(25^{\circ} \mathrm{C}\right)$ and $4.01\left(25^{\circ} \mathrm{C}\right)$. Ammonium was also determined using a method based on the diazotization of phenol and subsequent oxidation of the diazo compound to yield a blue color (measured wavelength: $640 \mathrm{~nm}$ ). The $\mathrm{Mg}$ concentration was also determined using inductively coupled plasma atomic emission spectrometry after 200-times' dilution of the acidified fluid samples. Furthermore, 1-2 ml fluid samples were collected for REE analysis and acidified on the ship to less than $\mathrm{pH} 2$ using ultra-pure $\mathrm{HCl}$ without filtration. Consequently, we were able to measure total (dissolved and acid soluble particulate) REE concentrations in fluid samples.

The REE analyses were performed using a mixture of $65 \%$ bis (2-ethylhexyl) hydrogen phosphate and 35\% 2ethylhexyl dihydrogen phosphate, followed by back-extraction with $6 \mathrm{M} \mathrm{HCl}$ in the laboratory of the Ocean Research Institute, Univ. Tokyo. Concentrations of REE were measured using ICP-MS (PMS-2000; Yokogawa Analytical Systems Inc.) (Zhang and Nozaki, 1996; Alibo and Nozaki, 1999). Triplicate analyses for each seawater sample provided relative standard deviations of $0.6-2.5 \%$ for REE, except for $\mathrm{Ce}(9.5 \%)$. Procedural blanks averaged $(n=7$, in pmol kg-1) are: $0.45 \pm 0.12$ for $\mathrm{Y}, 0.14 \pm 0.03$ for $\mathrm{La}, 0.59 \pm 0.14$ for $\mathrm{Ce}, 0.041 \pm 0.007$ for $\mathrm{Pr}, 0.14 \pm$ 0.03 for $\mathrm{Nd}, 0.038 \pm 0.004$ for $\mathrm{Sm}, 0.015 \pm 0.002$ for $\mathrm{Eu}$, $0.057 \pm 0.027$ for $\mathrm{Gd}, 0.007 \pm 0.002$ for $\mathrm{Tb}, 0.036 \pm 0.007$ for Dy, $0.008 \pm 0.002$ for Ho, $0.035 \pm 0.009$ for Er, 0.006 \pm 0.001 for $\mathrm{Tm}, 0.038 \pm 0.012$ for $\mathrm{Yb}$, and $0.007 \pm 0.002$ for Lu. These analytical blanks and detection limits (three times the standard deviations) were sufficiently low to interpret the low dissolved REE concentrations reliably in surface waters, including monoisotopic elements (Y, $\mathrm{Pr}, \mathrm{Tb}, \mathrm{Ho}$ and $\mathrm{Tm})$. Recoveries of $100 \pm 5 \%$ for ${ }^{115} \mathrm{In}$ were obtained in all analyses.

\section{RESULTS}

REE distributions in the water column at Yonaguni Knoll $I V$

We obtained three vertical REE distributions in the water column above Yonaguni Knoll IV. The horizontal distance from the hydrothermal vent site increases as SPOT-5 < SPOT-1 < SPOT-4. Results of REE concentrations are listed in Table 1 and described as vertical profiles in Fig. 2. Light transmission of seawater indicated that the hydrothermal buoyant plume expanded from 1000 $\mathrm{m}$ to $1200 \mathrm{~m}$ at SPOT-5 (Fig. 3). The Nd concentrations varied $4.6-30 \mathrm{pmol} \mathrm{kg}^{-1}$ within the water column at 


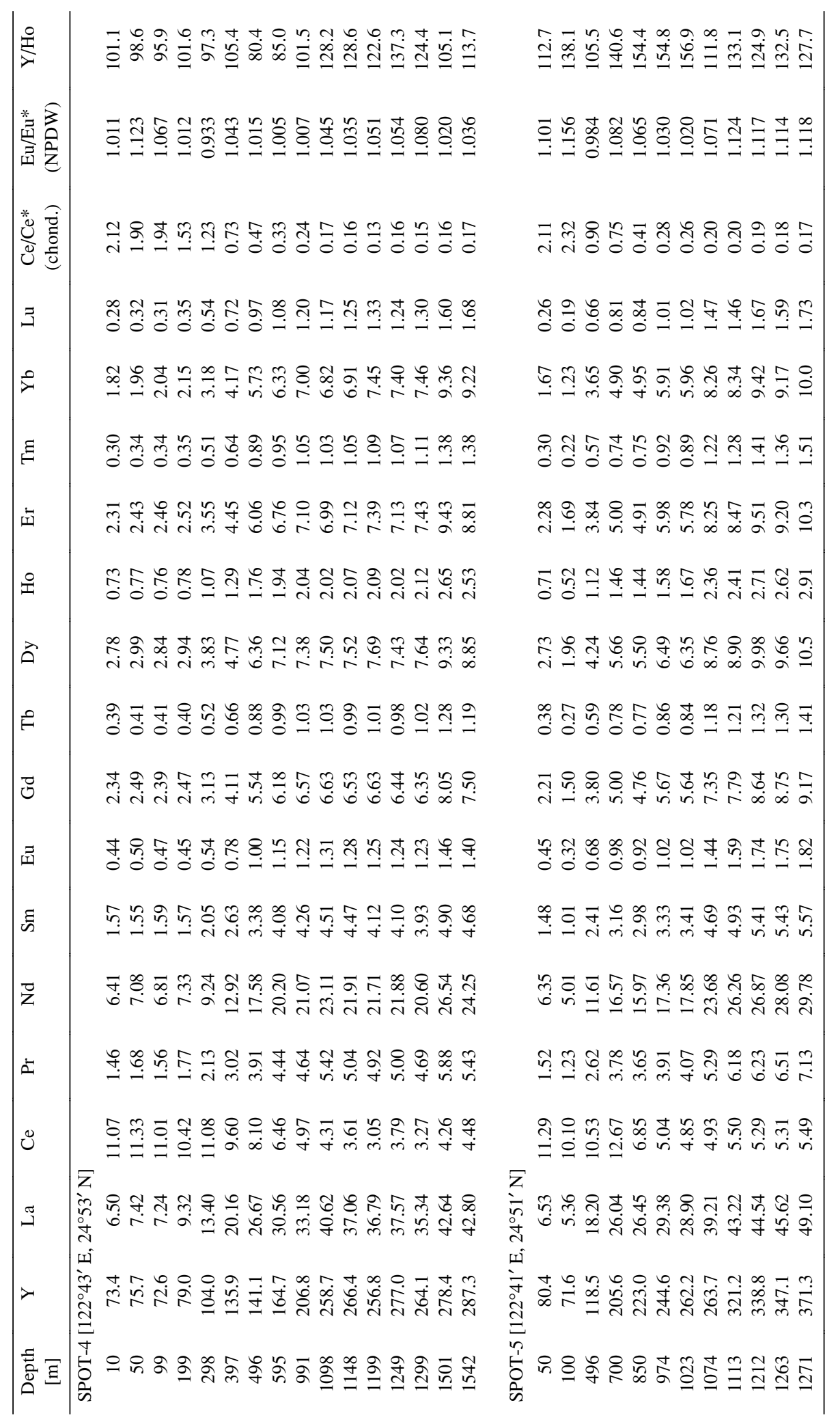




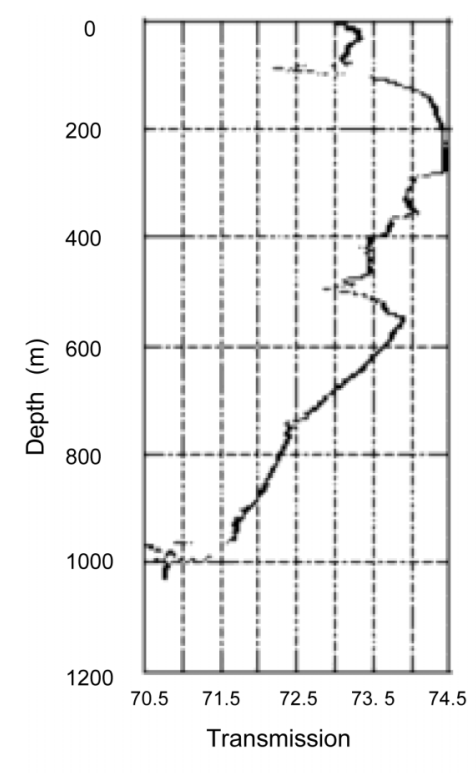

SPOT-1
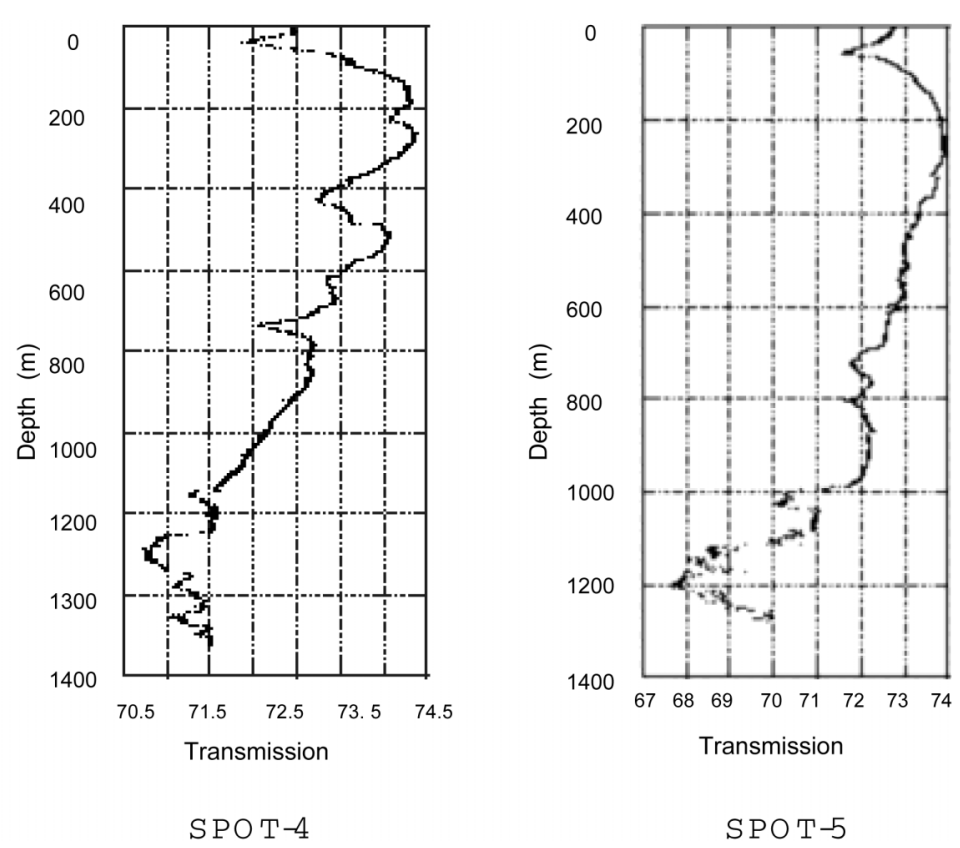

Fig. 3. Light transmission in the seawater column.

Yonaguni Knoll IV compared with the earlier observation in the western North Pacific seawater (Zhang and Nozaki, 1998). The REE(III) concentrations showed considerable horizontal variation among the three sites at 800-1200 m, especially for LREE: some examples are $\mathrm{Nd}$, which varied $23.9 \mathrm{pmol} \mathrm{kg}^{-1}$ at $793 \mathrm{~m}$ of SPOT-1, $21.1 \mathrm{pmol} \mathrm{kg}^{-1}$ at $991 \mathrm{~m}$ of SPOT-4, and $16.0 \mathrm{pmol} \mathrm{kg}-1$ at $850 \mathrm{~m}$ of SPOT-1. In the water column, active particle scavenging can reduce the dissolved REE(III) concentrations in seawater (Nozaki, 2001). However, Sholkovitz et al. (1994) and Alibo and Nozaki (1999) pointed out that particle scavenging of REE contributes less than 5\% of the concentrations in the seawater (except for Ce (III, IV)). Dissolved Ce profiles appeared to be somewhat more complex than those of other REE because Ce(III) readily oxidizes to $\mathrm{Ce}(\mathrm{IV})$ in a marine environment. Biological mediation (Moffett, 1990) and/or inorganic adsorption reaction with the $\mathrm{MnO}_{2}$ particle surface (Tachikawa et al., 1997, 1999) induces Ce scavenging from seawater. The Ce concentrations at SPOT- 1 and SPOT- 4 are much lower in deeper waters: $10 \mathrm{pmol} \mathrm{kg}-1<300 \mathrm{~m}$ and $5 \mathrm{pmol}$ $\mathrm{kg}^{-1}$ or less at $>1000 \mathrm{~m}$. In contrast, at SPOT-5, the maximum concentration was observed at $700 \mathrm{~m}$ depth, with decreased concentrations concomitant with increased depth. Cerium also displayed unusual variation, as did other dissolved REE. There was no possible locally limited input source of dissolved REE. For that reason, a large horizontal variation of REE is inferred to have resulted from the elimination of REE within a few square kilometers. One candidate for an elimination mechanism is adsorptive scavenging on the suspended matter originated from the slope of knoll sediments. However, such a diffusive supply of suspended matter from the knoll would not be localized. The mechanism would have to be more locally observed as the transmission anomaly in SPOT-5 (Fig. 3). Then, REE must be removed by scavenging on the large amount of suspended matter in a hydrothermal plume. We also measured concentration and composition of REE in the hydrothermal fluid samples to evaluate the contribution of hydrothermal activities on the REE distribution in surrounding seawater.

\section{REE in hydrothermal fluid samples}

Table 2 shows REE concentrations in hydrothermal fluids collected at nine chimney sites of Yonaguni Knoll IV. Fluids are substantially enriched in REE compared to seawater (NPDW, Nozaki et al., 1999) by factors of 3000 in Ce, 1000-10000 in Eu and 100 in other REE. Those REE concentration levels are consistent with previous investigations of the East Pacific Rise (EPR) (Klinkhammer et al., 1994a; Douville et al., 1999) and the Trans-Atlantic Geotraverse (TAG; Douville et al., 1999). The chondrite-normalized REE patterns of fluids are shown in Fig. 4. The most remarkable feature compared to NPDW is Eu enrichment, which had no negative Ce-anomaly. This is the most common characteristic of the hydrothermal fluid REE observed in many fluid samples in the world's oceans (Mitra et al., 1994; Klinkhammer et al., 1994a, b; Douville et al., 1999). These characteristics of REE compositions in fluids are 


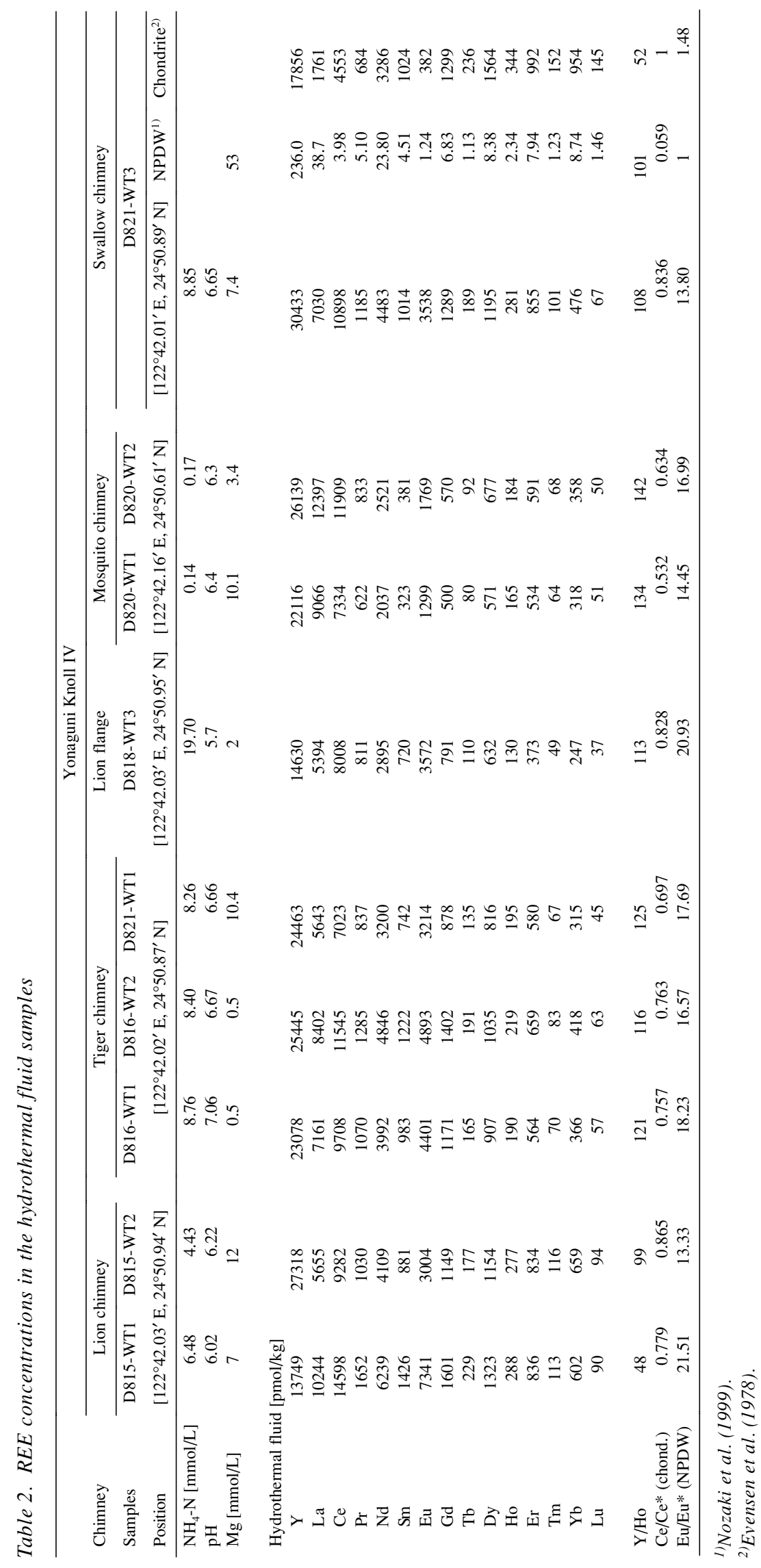




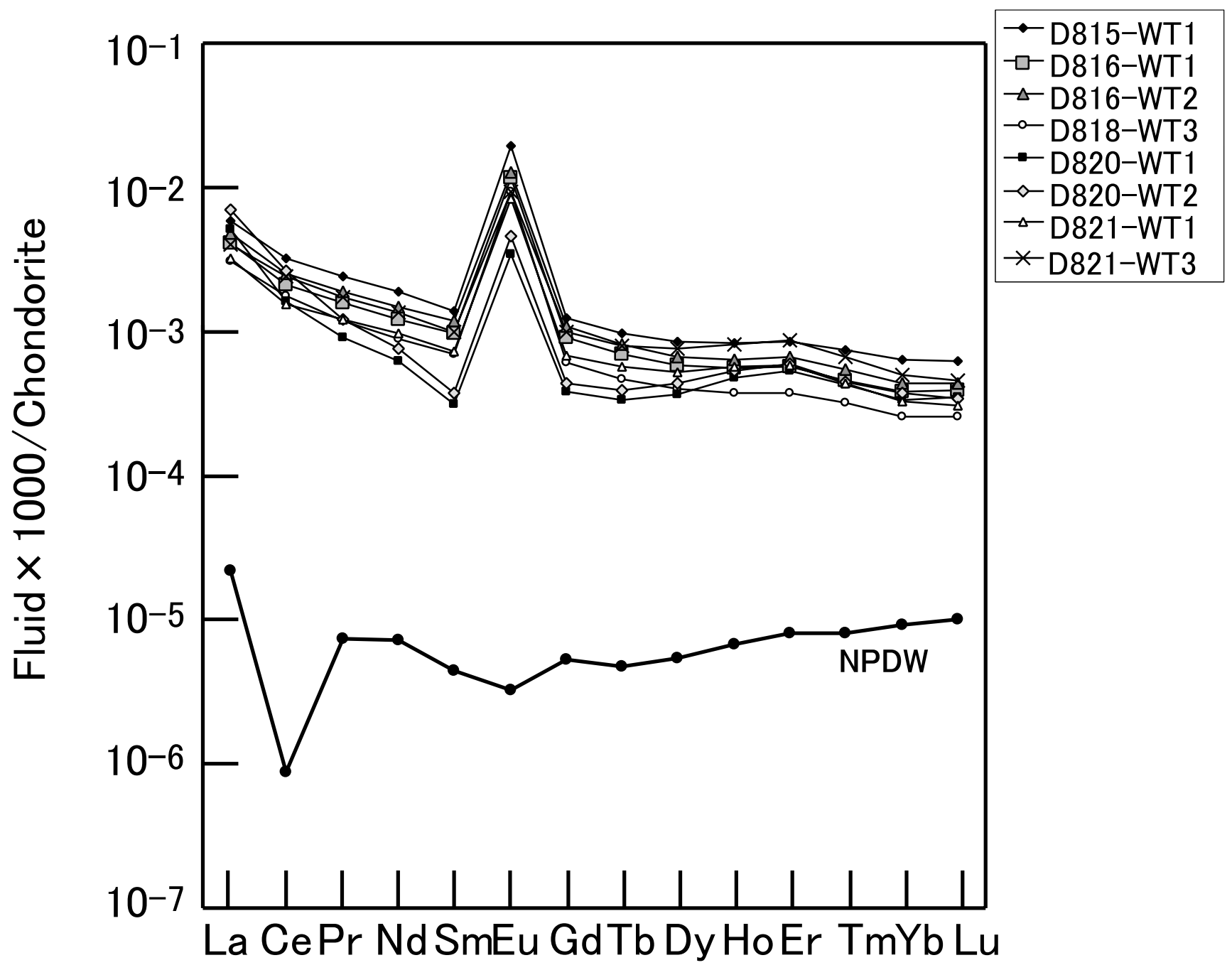

Fig. 4. Chondrite-normalized REE patterns of Yonaguni Knoll IV fluids.

caused by interaction between heated seawater and plagioclase phenocrysts in basalt, during alteration processes at high temperatures (Campbell et al., 1988; Klinkhammer et al., 1994a, b; Douville et al., 1999). Klinkhammer et al. (1994b) presented that sedimenthosted systems of Escanaba and Marianas showed similar features. Hot seawater and host-rock interaction engender a systematic change of REE composition from La to Lu (except for the Eu-anomaly) in a chondrite-normalized pattern. However, the REE patterns of Yonaguni Knoll IV fluid showed flat HREE compositions from Ho to Lu. We present an explanation for flat HREE in the fluid at the sediment-host Okinawa Trough.

\section{Discussion}

REE in the hydrothermal plume

Previous studies identified triple-layered plumes at
SPOT-5 using a methane profile; they were centered at $800 \mathrm{~m}, 1050 \mathrm{~m}$ and $1200 \mathrm{~m}$ (Nishida and Gamo, 2004). The $\mathrm{CH}_{4}$ concentration and carbon stable isotope at 1200 $m$ depth indicated that active microbial $\mathrm{CH}_{4}$ oxidation caused the $\delta^{13} \mathrm{C}$ increase of residual $\mathrm{CH}_{4}$ as the plume aged. A plume signal was also observed at $1200 \mathrm{~m}$ at SPOT-4 in Mn along with transmission profiles (Doi et al., 2004). SPOT-5 is the closest station to the hydrothermal vent (Fig. 1). Figures 5a and 5b illustrate Ce-anomalies [defined according to the equation $\mathrm{Ce} / \mathrm{Ce}^{*}=2 \mathrm{Ce}$ / $\left.\mathrm{Ce}_{\text {Chondrite }} /\left(\mathrm{La} / \mathrm{La}_{\text {Chondrite }}+\operatorname{Pr} / \operatorname{Pr}_{\text {Chondrite }}\right)\right]$ and Eu-anomalies (defined as the equation $\mathrm{Eu} / \mathrm{Eu}^{*}=2 \mathrm{Eu} / \mathrm{Eu}_{N P D W} /(\mathrm{Sm} /$ $\left.\mathrm{Sm}_{N P D W}+\mathrm{Gd} / \mathrm{Gd}_{N P D W}\right)$ at the depth of plume center, as predicted by the $\mathrm{CH}_{4}$ anomalies. The positive Eu-anomaly is the salient feature of hydrothermal fluid composition; $\mathrm{Ce}$ is the most sensitive indicator among the REE, displaying the particle scavenging activity in the water column due to its higher particle affinity. Additionally, nor- 

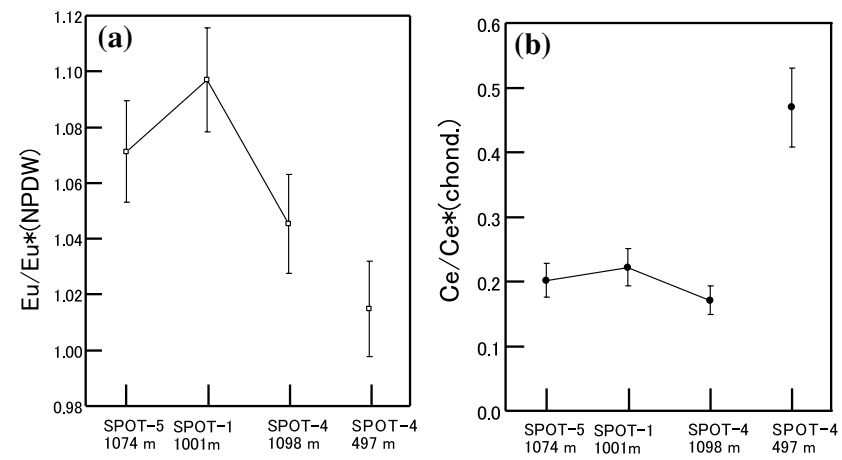

Fig. 5. a) Horizontal variation of Eu-anomalies in the plume center, defined as Eu/Eu* $=2 \times E u / E u_{N P D W} /\left(S m / S m_{N P D W}+G d /\right.$ $\left.G d_{N P D W}\right)$ and b) Ce-anomalies, defined as $2 \times \mathrm{Ce} / \mathrm{Ce} e_{\text {Chondrite }}$ $\left(\right.$ La/La $\left.a_{\text {Chondrite }}+\operatorname{Pr} / \mathrm{Pr}_{\text {Chondrite }}\right)$. The decrease of Ce-anomalies normalized with chondrite indicates successive particle scavenging. The plume center was predicted by the $\mathrm{CH}_{4}$ anomalies. The values at $496 \mathrm{~m}$ depth of SPOT-4 are representative of ambient normal seawater values.

mal seawater values at $497 \mathrm{~m}$ depth at SPOT-4, where no anomalous values were observed in the transmission, manganese or methane profiles, were also plotted. The Eu-anomaly in the plume decreased with increasing distance from the vent site from SPOT-5 to SPOT-4 (Fig. 5a). The REE concentrations in both sites were of the same level as normal seawater in the western North Pacific (Zhang and Nozaki, 1998). However, the REE composition reflected the hydrothermal fluid signature. This reflection suggested that the REE, supplied by hydrothermal fluid, did not act as an additional source of REE to the surrounding seawater, but its hydrothermal influence is apparent in REE compositions.

The negative-Ce anomaly increase, or the decreased value of $\mathrm{Ce} / \mathrm{Ce}^{*}$, indicated continuous scavenging of REE (Fig. 5b) caused by adsorption of particles in the plume. The decreased light transmission (Fig. 3) indicated the large amount of particles in the plume. Cerium anomalies in the plume depth at three SPOT stations were greater than that of normal seawater at $496 \mathrm{~m}$ depth of SPOT-4, suggesting that the REE removal was more active in the plume than in the ambient water column. Scavenging occurred successively during transport processes in seawater. The Eu- and Ce-anomalies sensitively reflected the influence of the hydrothermal activity and expansion around the vent field.

Hydrothermal fluid character of the sediment-hosted Okinawa Trough

The REE compositions of the fluid at Yonaguni Knoll IV resemble those of the Mid-Oceanic ridge sites, showing LREE enrichment, positive Eu-anomalies, and no Ceanomalies. However, the heavier-REE (HREE) composi-

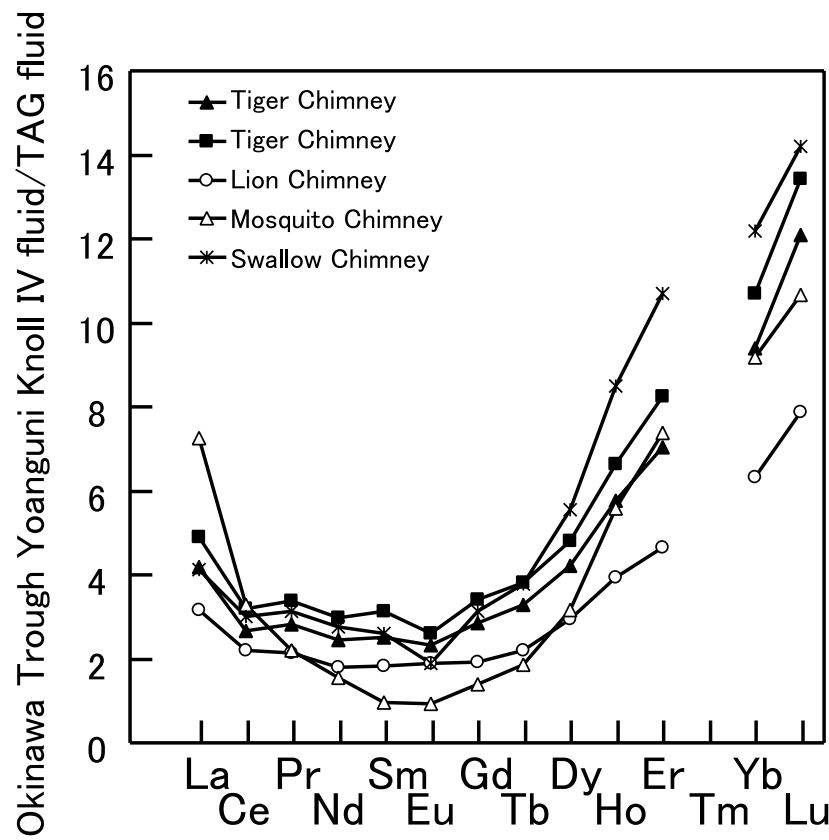

Fig. 6. REE concentration ratios of fluids collected at Yonaguni Knoll IV to TAG fluid (HS88 10/1 TAG; Douville et al., 1999).

tion of the Yonaguni Knoll IV fluid was almost flat after chondrite-normalization, even though the mid-oceanic ridge (TAG, EPR) showed a systematic decrease from $\mathrm{Tb}$ to $\mathrm{Lu}$.

Previous studies have revealed that the chondrite-normalized REE pattern of intermediate and silisic rocks forming the middle Okinawa Trough showed a gentle LREE decrease and almost flat or slightly increasing HREE with the atomic number (Shinjo and Kato, 2000). These characteristics resemble the REE composition in the fluid sample collected at the Yonaguni Knoll IV. However, the REE compositions of host rocks observed in the Okinawa trough can only slightly explain the REE characteristics of the fluid because silisic rocks forming the middle Okinawa Trough (Shinjo and Kato, 2000) have no Eu-enrichment: they have only small negative Euanomalies. Furthermore, the REE composition of hydrothermal fluids must reflect the elemental fractionations induced by interaction of hot water and rocks. However, we await further analyses of minerals at vent sites before attempting to explain the rock-water interaction effects on REE composition. This paper describes a possible explanation of the flat HREE patterns aside from the transcript of REE in the host rock. The most likely candidate for the additional REE source of the fluid is the covering sediment at the Okinawa Trough. Figure 6 described the REE concentration in the Yonaguni Knoll fluid over the TAG fluid (HS88 10/1 TAG; Douville et al., 1999). Although the REE compositions in atomic number from $\mathrm{Ce}$ 


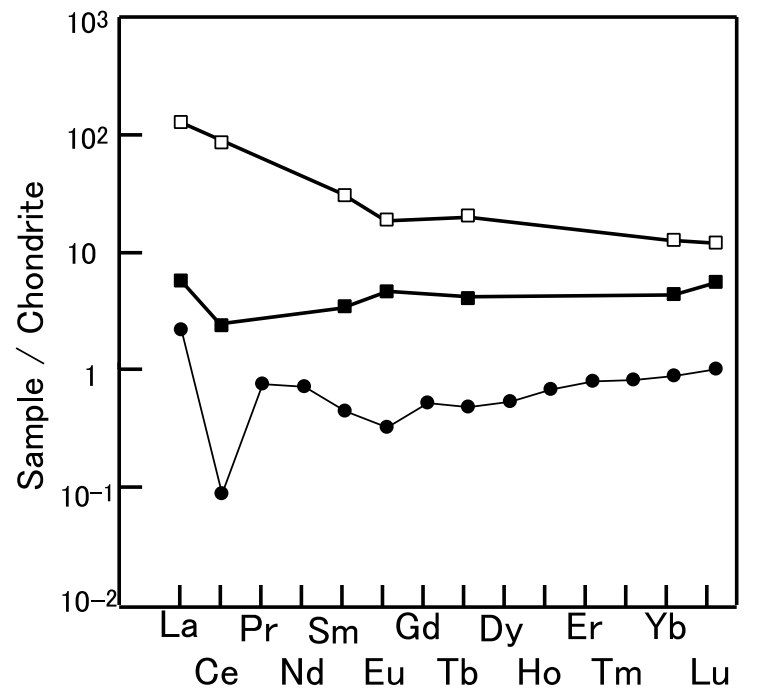

$\rightarrow-D 231$ Sediment (near the vent field)

$\square-D 238$ Sediment (pelagic sediment at the Okinawa Trough) $\rightarrow$ NPDW $\times 10^{5}$

Fig. 7. Chondrite-normalized REE patterns of NPDW (Nozaki et al., 1999) and D231 (near the vent field sediment), D238 (pelagic sediment at the Okinawa Trough) samples (Masuda et al., 1978). The REE composition in D231 sample reflected the signatures of both the hydrothermal fluid and seawater because a large amount of suspended matter resulted from fluid venting removed REE in not only in the fluid but also in seawater. On the other hand, REE composition of D238 reflects the elemental fractionation between particulate and dissolved forms within the water column.

to Gd were similar for the two hydrothermal types, La and HREE (Tb-Lu) were enriched in the Yonaguni Knoll fluids. Enrichment characteristics of REE at Yonaguni Knoll IV fluid over the TAG fluid coincides with the pore water composition in the POC-rich sediments reported by previous work. Haley et al. (2004) presented the greatly enriched HREE pattern of pore water, increasing with atomic mass, $\mathrm{Lu}>\mathrm{Yb}>\mathrm{Tm}>\mathrm{Er}>\mathrm{Ho}$ in the PAASnormalized REE patterns. Those REE characteristics can apply even in the chondrite normalized case. Systematic HREE enrichment is explainable by its strong complexation nature with organic ligands (Byrne and Kim, 1990). Although we have no direct information for the sediment at the Yonaguni Knoll IV, Masuda et al. (1978) reported a flat HREE composition of sediments compared to chondrite at the Okinawa Trough (Fig. 7). Those are the only available REE data of the sediment at this site measured by neutron activation analysis, even though not all lanthanides are included in previous data. The chondrite-normalized REE pattern of the pelagic sediment collected at the Okinawa Trough was characterized by higher LREE than HREE and a flat HREE pattern. On the other hand, the sediment pattern near the vent field

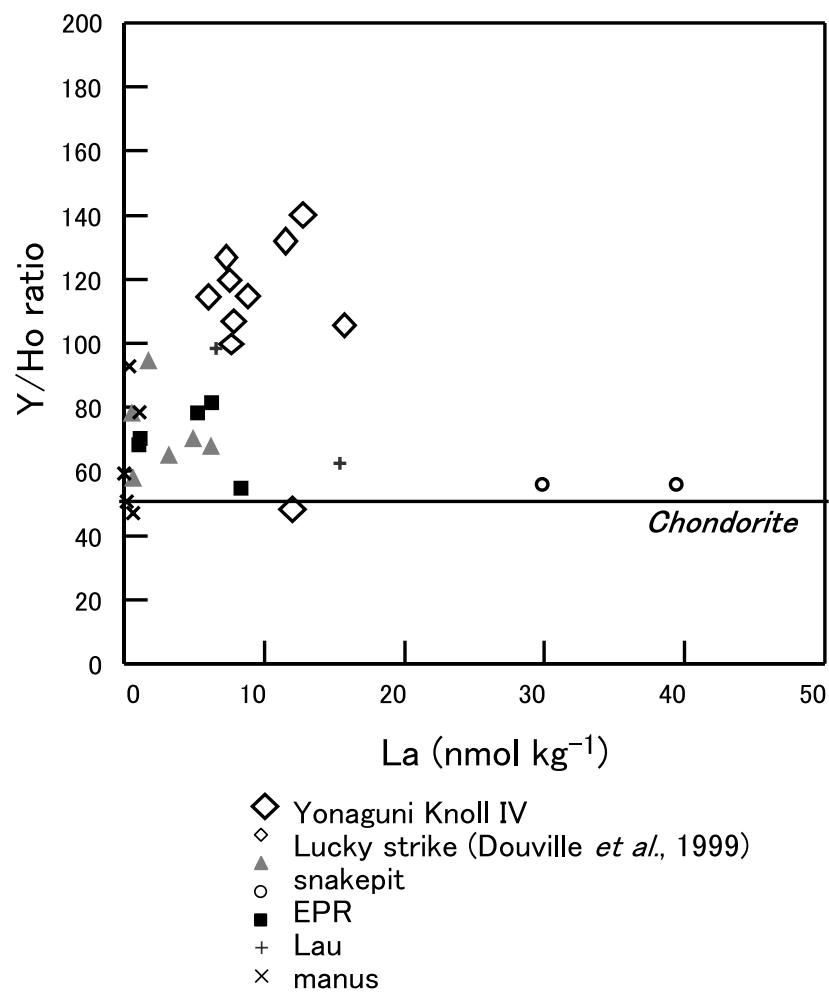

Fig. 8. The Y/Ho molar ratio to the La concentrations in various hydrothermal vent fluids.

showed higher HREE than LREE, which also supports the explanation that the sediments can affect the fluid REE composition. Active scavenging at the vent site removes the dissolved REE from surrounding seawater, which has a higher HREE composition. During mixing of the fluid with seawater, drastic changes of $\mathrm{pH}$ and temperature produce large amounts of particulate matter, followed by substantial removal of trace elements, even from ambient seawater, because of adhesion or coprecipitation with particles. Therefore, the seawater undergoes a net depletion of REE as a consequence of hydrothermal activity (Mitra et al., 1994). High La and flat HREE patterns of Yonaguni Knoll fluid underscore the importance of the influence of covering sediments near the vent for fluid REE composition as well as rock and hot-water interaction.

Figure 8 depicts the Y/Ho molar ratios over the La concentrations in various hydrothermal vent fluids. In Okinawa Trough fluids, La concentrations were similar to those reported among previous data for the mid-oceanic ridge. On the other hand, Y/Ho molar ratios in the Okinawa Trough (48-142) are demonstrably higher than those at other hydrothermal sites $(<98)$. Douville et al. (1999) and Bau and Dulski (1999) reported that the fluid samples in the Mid-Atlantic Ridge and EPR were near the chondrite values of about 50 (Evensen et al., 1978) or 


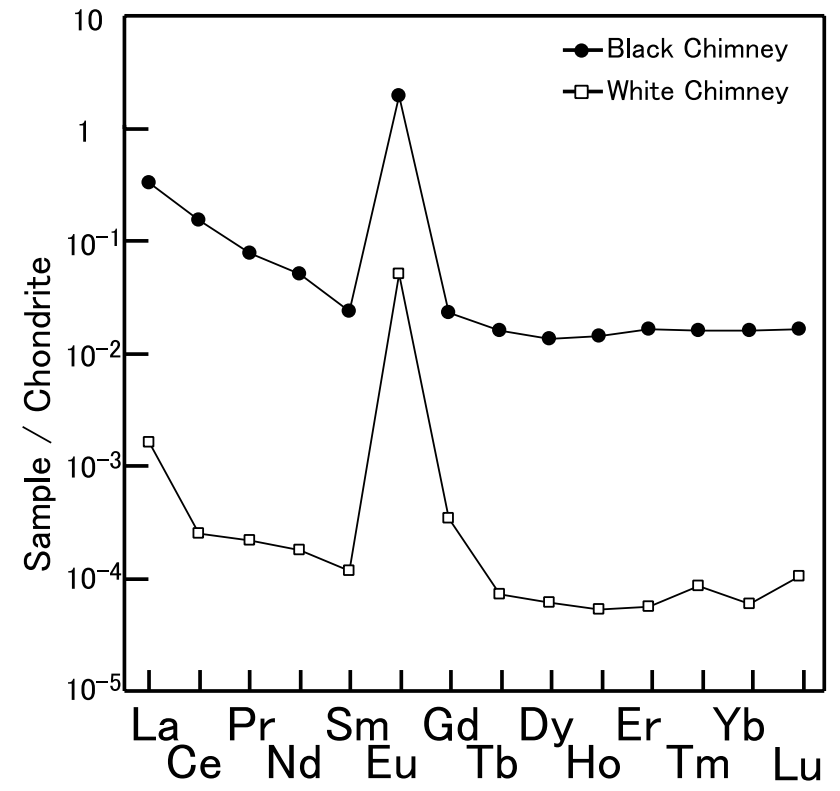

Fig. 9. Chondrite-normalized REE patterns of hydrothermal deposits (chimney) collected at the Okinawa Trough (Hongo and Nozaki, 2001).

slightly higher. They have explained that the excess Y/ Ho values over the chondrite were caused by mixing with seawater $(\mathrm{Y} / \mathrm{Ho}$ is around 100). Higher $\mathrm{Y} / \mathrm{Ho}$ ratios in fluids were also reported at Vienna Woods in the Manus Basin (Douville et al., 1999). At the Manus Basin site, seawater has insufficient time to react with rocks completely because of short and shallow convective cells; the fluid might therefore maintain the seawater $\mathrm{Y} / \mathrm{Ho}$ value (Douville et al., 1999). In contrast, the Y/Ho ratio in the Okinawa Trough was greater than 100: as high as seawater. Scavenging by iron and manganese oxide particles in the water column increase the $\mathrm{Y} / \mathrm{Ho}$ ratio, as indicated by the fact that the seawater value $(\mathrm{Y} / \mathrm{Ho}=100)$ is higher than that of source materials $\left(\mathrm{Y} / \mathrm{Ho}_{\text {rocks }}=c a\right.$. 55). The seawater $\mathrm{Y} / \mathrm{Ho}$ values at the SPOT stations are greater than 100 ( $c a$. 156) and increase toward the vent site (Fig. 1b), reflecting active particle scavenging and elemental fractionation between $\mathrm{Y}$ and Ho within the water column. The higher $\mathrm{Y} / \mathrm{Ho}$ ratios than those of other hydrothermal site are explainable by the higher $\mathrm{Y} / \mathrm{Ho}$ values in the water column compared to those of other vent sites.

\section{Fluid dilution through mixing with ambient seawater}

Previous work in the Okinawa Trough (Hongo and Nozaki, 2001) revealed that the REE pattern in the hydrothermal deposits (chimney) showed flat HREE and positive Eu-anomaly (Fig. 9), which is similar to the fluid observed in this study. This suggests that the REE character of hydrothermal fluid was preserved in the precipi-

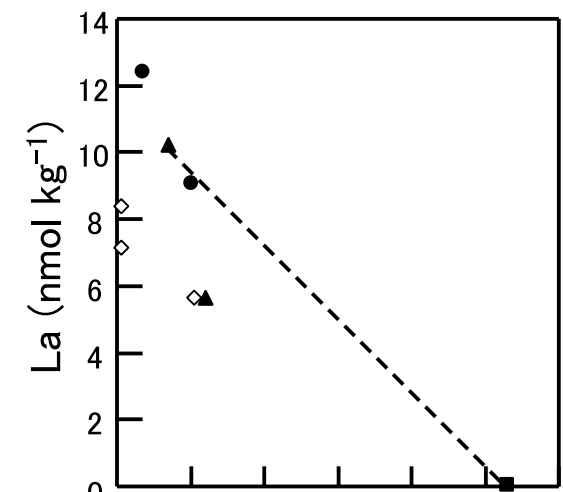

- Normal Seawater

$\Delta$ Lion Chimney

$\diamond$ Tiger Chimney

$\bullet$ Mosquito Chimney
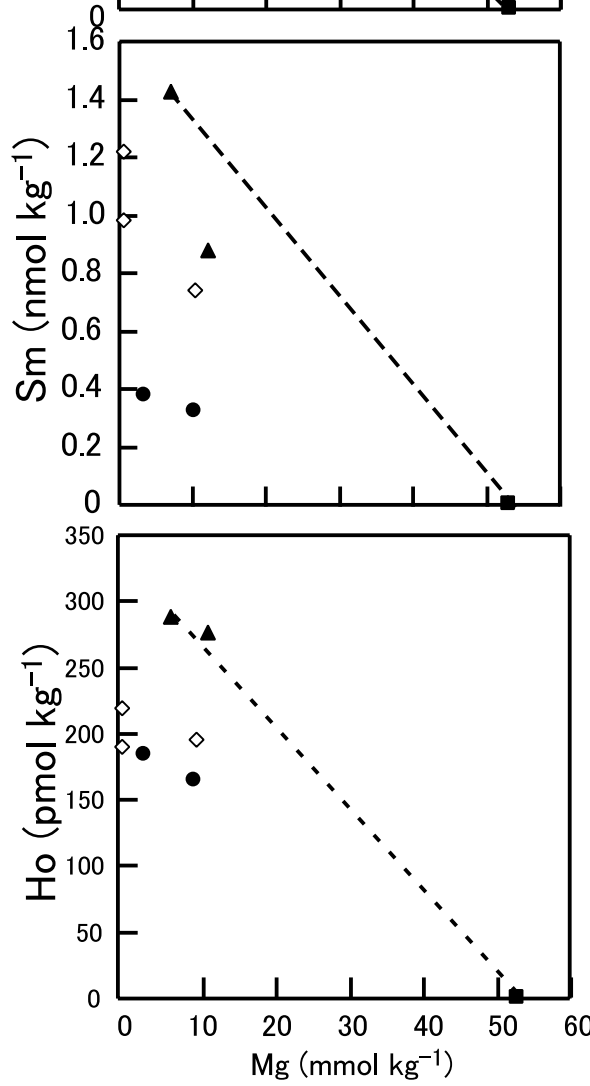

Fig. 10. La (LREE), Sm (MREE) and Ho (HREE) concentrations in the fluid against $M g$ concentrations. Closed squares are normal seawater values. See the text.

tates. In addition, the fact that surrounding seawater lost the fluid composition immediately (Hongo and Nozaki, 2001) appears that the most part of REE in the fluid precipitates within the vent site and does not distribute over a wide area. Therefore, we discuss here the change of REE composition within the vent site to elucidate the distribution of REE after spouting into the seawater. We compared the REE concentrations in the fluid of various mixing ratios with seawater. Figure 10 depicts $\mathrm{La}, \mathrm{Sm}$ and Ho concentrations versus $\mathrm{Mg}$ concentration. We can draw a simple dissolution line by assuming that the Mg con- 

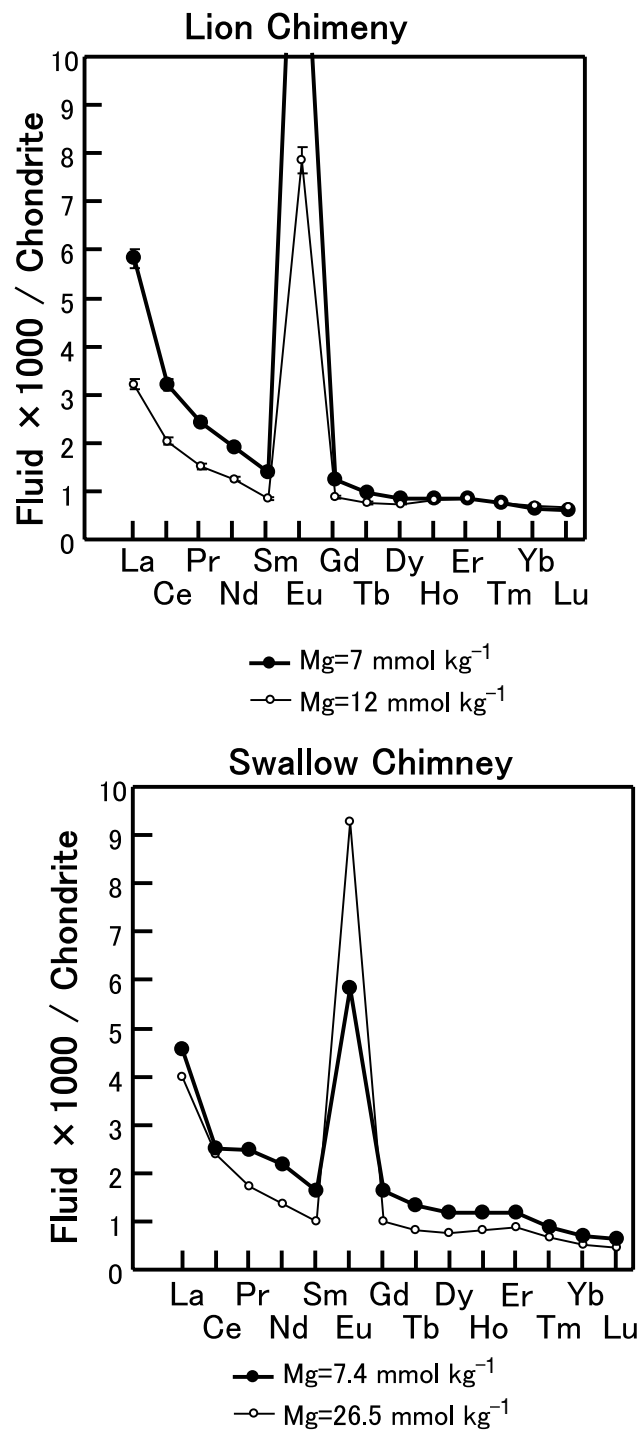
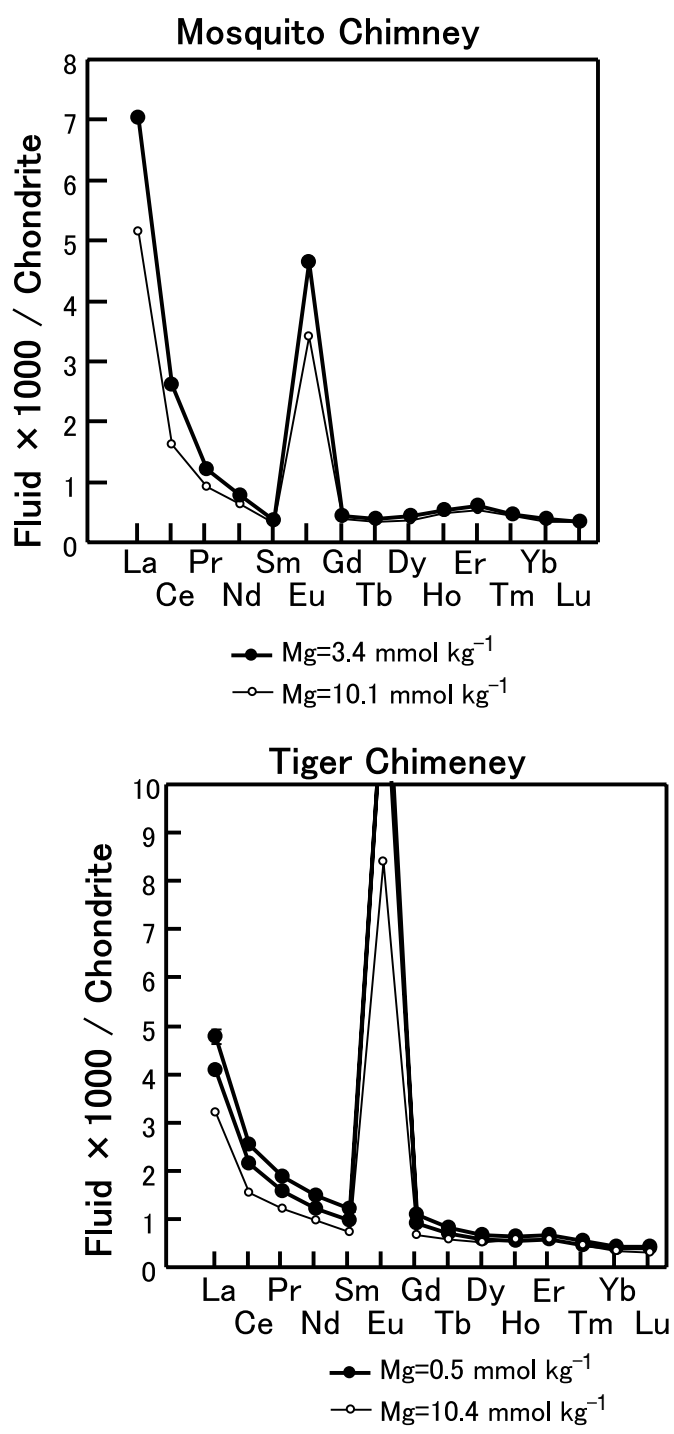

Fig. 11. Variation of REE compositions in fluid samples collected at the chimneys. The REE patterns are chondrite-normalized.

centration in normal seawater is $[\mathrm{Mg}]$ ambient $=53 \mathrm{mmol}$ $\mathrm{kg}^{-1}$ and that, in the end-member, fluids are zero (Von Damm et al., 1985). The La concentration was less than the expected value estimated from $\mathrm{Mg}$ concentrations; that feature was commonly observed among the LREE. On the other hand, Ho and Er (HREE) concentrations are explainable roughly by mixing of fluids with the seawater. The LREE deficiency compared to estimated values indicates that some preferential removal mechanism affected the REE composition in the fluid.

When the fluid is mixed with ambient seawater, many kinds of metals might precipitate with sulfides, carbonates and oxides from the water phase because solubility is lower by higher $\mathrm{pH}$ and lower temperature seawater compared to the acidic and high temperature hydrothermal fluid. However, Mitra et al. (1994) stated that fractionation was not observed in the fluid at the MidAtlantic Ridge during mixing of hydrothermal vent fluids with seawater. Hongo and Nozaki (2001) obtained REE compositions in the hydrothermal deposits of carbonates and sulfides that were mainly collected at the northwestern Okinawa Trough. Carbonate deposits containing less than $6 \%$ sulfide showed the characteristic REE composition with a positive Eu-anomaly, LREE systematic enrichment, and almost flat HREE. Carbonate deposits that contain less than $0.5 \%$ sulfide exhibited similar features to those of higher sulfide compositions (Fig. 9). These results indicate that the REE in the fluid samples were fractionated through co-precipitation with the sulfide and carbonate deposits at the vent field. Figure 11 illustrates the chondrite-normalized REE patterns of fluids samples collected at each chimney site. Lighter REE con- 


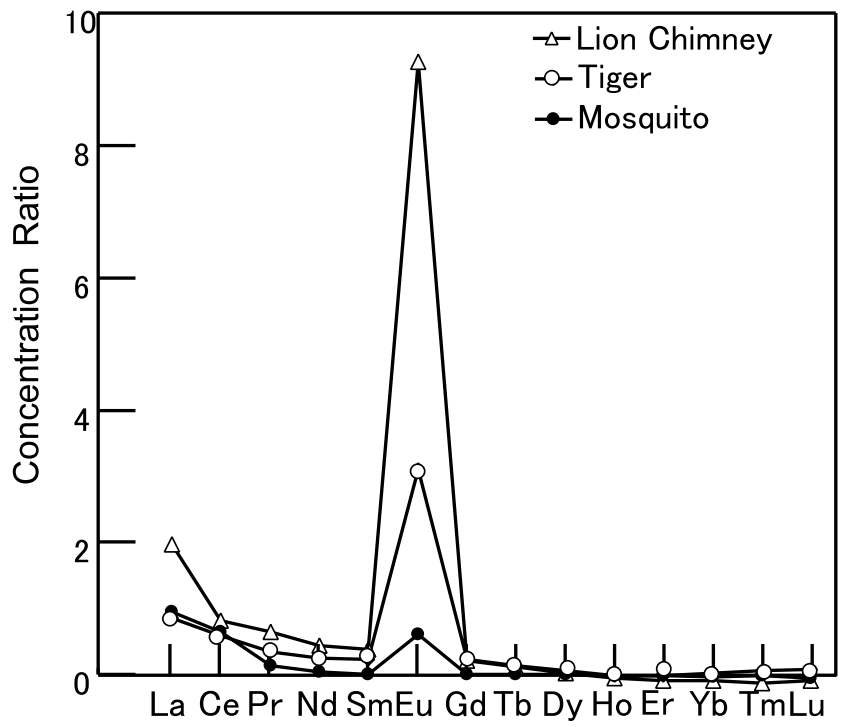

Fig. 12. Fractionated REE patterns during early mixing between fluid and seawater (chondrite-normalized). Theoretical dilution processes were incorporated.

tent and positive Eu-anomalies were slightly lower concomitant with increasing $\mathrm{Mg}$ concentrations at all sites. The LREE reduction with increasing $\mathrm{Mg}$ is clear compared to HREE. Additionally, Fig. 12 portrays the differences between calculations using the simple dilution model and observed values of fluid REE. Calculation of REE concentrations was performed using NPDW ([Mg] $\left.=53 \mathrm{mmol} \mathrm{kg}^{-1}\right)$ and fluid $(\mathrm{Mg}=0)$ extrapolation. Europium was fractionated from other REE during dilution with seawater. Furthermore, the LREE compositions changed compared to those of HREE compositions. The characteristic behavior of Eu might reflect its different chemical speciation: $\mathrm{Eu}^{2+}$ is inferred to be the predominant species at temperatures greater than $250^{\circ} \mathrm{C}$, high pressure, and low $\mathrm{p} \varepsilon$ (Sverjensky, 1984). The other REE will be present as REE(III) ions. Unfortunately, we have insufficient supportive hydrological and chemical information (i.e., temperature, $\mathrm{p} \varepsilon$, and anion species composition), but it is convincing that Eu behavior is separate from other strictly trivalent REE.

Except for Eu, elemental fractionation during the dilution process of fluids with seawater is similar to that in the water column (Sholkovitz et al., 1994; Nozaki et al., 1999; Bertram and Elderfield, 1993). Nevertheless, Ce deficiency, which is the typical feature of scavenging on oxidative condition in water column, was negligible in the REE fractionation in the fluid and seawater mixing. The removal of Ce from seawater is related to its oxidation process, like that for Mn, via biomediation (Moffett, 1990) or inorganic oxidation processes (Koeppenkastrop and DeCarlo, 1992). The absence of Ce depletion in fluid mixing suggests that the dominant factor of REE fractionation is not particle adhesion, as in the water column, but precipitation with hydrothermal minerals that are particular to mechanisms at the vent. Actually, the REE composition in the hydrothermal deposits (Hongo and Nozaki, 2001) showed the same fractionation pattern as that during the fluid dilution. The REE composition in the fluid sample can present the fractionation induced by removal with deposits. The REE distribution of the hydrothermal vent field was influenced strongly by at least two mechanisms. One is active particle scavenging; the other is precipitation with the hydrothermal deposits. Both mechanisms can reduce the LREE systematically, but incorporation with sulfate and carbonate deposits induces peculiar Eu elimination with no Ce deficiency. Precise analysis of fluid REE is a useful tool to reveal the vent fluid chemistry.

\section{CONClusion}

Our results describe the vertical distributions of REE in the water column near vent fields at the Okinawa Trough back-arc basin. The REE vertical distributions at three vents at the Yonaguni Knoll IV site showed a hydrothermal buoyant plume at 1000-2000 m, where the $\mathrm{CH}_{4}$ increases anomalously. Considerable variation of the horizontal REE concentration indicated the existence of a hydrothermal plume containing a large amount of suspended mattes, which removed REE from seawater. Positive Eu-anomaly and negative Ce-anomaly respectively signified the dilution of the hydrothermal fluid signature and the activity of particle scavenging. The REE composition is a useful tool to trace the evolution of plume during lateral transport. Although REE in the hydrothermal fluid does not act as the net source of the world's oceans' REE budget, highly accurate analyses of REE enable us to trace the influence of hydrothermal activities using REE.

Analytical results of REE in the hydrothermal fluids collected at Yonaguni Knoll IV established the typical Eu enrichment and systematically increased lighter REE at the mid-ocean ridges. Higher REE (Ho-Lu) enriched compositions than those of TAG and EPR reflected the REE composition of covering sediments, which concentrates HREE over LREE. Furthermore, when the venting fluid mixed with seawater, REE in the fluids did not decrease linearly with increased $\mathrm{Mg}$ concentrations. This fact suggests that mixing of seawater with hydrothermal fluid induced particular elemental fractionation. Carbonate and sulfide precipitates seem to cause large anomalous $\mathrm{Eu}$ taking and non-selective removal of $\mathrm{Ce}$ from the solution, which are distinguishable from scavenging mechanisms by the Fe and Mn oxide particles in seawater. Precise analysis of fluid REE is a tool to reveal trace element behavior in hydrothermal fluid chemistry. 
Acknowledgments-We are grateful to two reviewers, Dr. H. Masuda and Dr. J. L. Charlou, for their helpful comments on the manuscript. We would like to thank the captains, officers and crew of $R / V$ Hakuho-maru (Chief Director H. Tokuyama), $M / S$ Yokosuka (Chief Director T. Nunoura), and the operation staff of the submersible "SHINKAI 6500" (JAMSTEC) for their kind cooperation during the cruises. We are indebted to $\mathrm{T}$. Oomori, H. Chiba and T. Noguchi for their cooperation in sampling on the Hakuho-maru. We thank Y. Nozaki for providing the opportunity of beginning this study. This work was partially supported by the Ministry of Education, Culture, Sports, Science, and Technology, Japan through a Grant-in Aid (No. 13304045) to the University of Tokyo (P.I., H. Obata).

\section{REFERENCES}

Alibo, D. S. and Nozaki, Y. (1999) Rare earth elements in seawater: particle association, shale-normalization, and $\mathrm{Ce}$ oxidation. Geochim. Cosmochim. Acta 63, 363-372.

Bau, M. and Dulski, P. (1999) Comparing yttrium and rare earths in hydrothermal fluids from the Mid-Atlantic Ridge: implications for $\mathrm{Y}$ and REE behavior during near-vent mixing and for the Y/Ho ratio of Proteozoic seawater. Chem. Geol. 155, 77-90.

Butterfield, D. A., Massoth, G. J., McDuff, R. E., Lupton, J. E. and Lilley, M. D. (1990) Geochemistry of hydrothermal fluids from axial seamount hydrothermal emissions study vent field, Juan-de-Fuca Ridge-subseafloor boiling and subsequent fluid-rock interaction. J. Geophys. Res-Solid Earth and Planets, 95(B8), 12895-12921.

Byrne, R. H. and Kim, K. H. (1990) Rare earth element scavenging in seawater. Geochim. Cosmochim. Acta 57, 519526.

Byrne, R. H. and Sholkovitz, E. R. (1996) Marine chemistry and geochemistry of the lanthanides. Handbook on the Physics and Chemistry of Rare Earths (Gschneider, K. A., Jr. and Eyring, L., eds.), 23, 497-593, Elsevier Science, Amsterdam.

Campbell, A. R., Palmer, M. R., Klinkhammer, G. P., Bowers, J. M., Edmond, T. S., Lawrence, J. R., Casey, J. F., Thompson, G., Rona, P. and Karson, J. A. (1988) Chemistry of hot springs on the Mid-Atlantic Ridge. Nature 335 , 514-519.

Doi, T., Obata, H. and Maruo, M. (2004) Shipboard analysis of picomolar levels of manganese in seawater by chelating resin concentration and chemiluminescence detection. Anal. Bioanal. Chem. 378, 1288-1293.

Douville, E., Bienvenu, P., Charlou, J. L., Donval, J. P., Fouquet, Y., Appriou, P. and Gamo, T. (1999) Yttrium and rare earth elements in fluids from various deep-sea hydrothermal systems. Geochim. Cosmochim. Acta 63, 627-643.

Evensen, N. M., Hamilton, P. J. and O'Nion, R. K. (1978) Rare earth abundance in chondritic meteorites. Geochim. Cosmochim. Acta 42, 1199-1212.

Gamo, T., Sakai, H., Kin, E., Shitashima, K., Yanagisawa, F., Ishibashi, J., Oomori, T., Yamano, M., Nojiri, Y., Tanaka, T., Matsumoto, T., Mitsuzawa, K. and Nagamuta, T. (1990) Geochemical studies on the Hydrothermal activity of the Mid-Okinawa Trough: A report on dive 416 of the
"SHINKAI 2000" and characterization of hydrothermal fluids from concentrations of major chemical components. Proc. the 6th Symposium on Deep-sea Research Using the Submersible “SHINKAI 2000" System, 51-62, Technical Reports of Japan Marine Science and Technology Center (JAMSTEC) (in Japanese).

Gamo, T., Sakai, H., Kim, E. S., Shitashima, K., Yanagisawa, F. and Ishibashi, J. (1991) High alkalinity due to sulfide reduction in the calm hydrothermal field, Okinawa Trough. Earth Planet. Sci. Lett. 107, 328-338.

German, C. R., Colley, S., Palmer, M. R., Khripounoff, A. and Klinkhammer, G. P. (2002) Hydrothermal plume-particle fluxes at $13^{\circ} \mathrm{N}$ on the East Pacific Rise. Deep-Sea Res. 49, 1921-1940.

Haley, B. A., Klinkhammer, G. P. and McManus, J. (2004) Rare earth elements in pore waters of marine sediments. Geochim. Cosmochim. Acta 68, 1265-1279

Hongo, Y. and Nozaki, Y. (2001) Rare earth element geochemistry of hydrothermal deposits and Calyptogena shell from the Iheya Ridge vent field, Okinawa Trough. Geochem. J. 35, 347-354.

James, R. H. and Palmer, M. R. (2000) Marine geochemical cycles of the alkali elements and boron: The role of sediments. Geochim. Cosmochim. Acta 64, 3111-3122.

Klinkhammer, G. P., Elderfield, H., Edmond, J. M. and Mitra, A. (1994a) Geochemical implications of rare earth element patterns in hydrothermal fluids from mid-ocean ridges. Geochim. Cosmochim. Acta 58, 5105-5113.

Klinkhammer, G. P., German, C. R., Elderfield, H., Greaves, M. J. and Mitra, A. (1994b) Rare-earth element in hydrothermal fluids and plume particles by inductively coupled plasma mass spectrometry. Mar. Chem. 45(3), 179-186.

Koeppenkastrop, D. and DeCarlo, E. H. (1992) Sorption of rareearth elements from seawater onto synthetic mineral particles-an experimental approach. Chem. Geol. 95, 251-263.

Masuda, H., Ishibashi, J., Kato, Y., Gamo, T. and Sakai, H. (1978) Oxygen isotope ratio and trace element composition of hydrothermal sediments from Okinawa Trough, collected with "SHINKAI 2000", Dive 231. The 3rd Symposium on Deep-sea Research Using the Submersible “SHINKAI 2000” System, 225-232, Technical Reports of Japan Marine Science and Technology Center (JAMSTEC) (in Japanese).

Michard, G., Albarede, F., Michard, A., Minster, J. F., Charlou, J. L. and Tan, N. (1984) Chemistry of solutions from the $13^{\circ} \mathrm{N}$ East Pacific Rise hydrothermal site. Earth Planet. Sci. Lett. 67, 297-307.

Mills, R. A. and Elderfield, H. (1995) Rare earth element geochemistry of hydrothermal deposits from the active TAG Mound, $26^{\circ} \mathrm{N}$ Mid-Atlantic Ridge. Geochim. Cosmochim. Acta 59, 3511-3524.

Mitra, A., Elderfield, H. and Greaves, M. J. (1994) Rare earth elements in submarine hydrothermal fluids and plumes from the Mid-Atlantic Ridge. Mar. Chem. 46, 217-235.

Moffett, J. W. (1990) Microbially mediated cerium oxidation in seawater. Nature 345, 421-423.

Nishida, S. and Gamo, T. (eds.) (2004) Preliminary Report of the Hakuho Maru Cruise KH-02-4 (The Sulu Sea and the Western Pacific): Studies on Biodiversity and Geochemical 
Cycles in the Sulu Sea and Its Adjacent Waters. Ocean Research Institute, The Univ. of Tokyo, $76 \mathrm{pp}$.

Nozaki, Y. (2001) Rare earth elements and their isotopes. Encyclopedia of Ocean Sciences, Vol. 4 (Steele, J. H., Thorpe, S. A. and Turekian, K. K., eds.), 2354-2366, Academic Press Inc., London.

Nozaki, Y. and Alibo, D. S. (2003) Importance of vertical geochemical processes in controlling the oceanic profiles of dissolved rare earth elements in the northeastern Indian Ocean. Earth Planet. Sci. Lett. 205, 155-172.

Nozaki, Y., Alibo, D. S., Amakawa, H., Gamo, T. and Hasumoto, H. (1999) Dissolved rare earth elements and hydrography in the Sulu Sea. Geochim. Cosmochim. Acta 63, 2171-2181.

Nunoura, T. (2004) Geomicrobiological and geochemical investigation of deep-sea hydrothermal vents in Yonaguni Knoll IV and Iheya North (YK04-05, Leg2) YokosukaShinkai 6500 Cruise Report, Japan Agency for Marine-Earth Science \& Technology.

Sakai, H., Gamo, T., Kim, E., Shitashima, S., Yanagisawa, K., Tsutsumi, M., Ishibashi, J., Sano, Y., Wakita, H., Tanaka, T., Matsumoto, T., Naganuma, T. and Mitsuzawa, K. (1990) Unique chemistry of the hydrothermal solution in the MidOkinawa Trough backarc basin. Geophys. Res. Lett. 17, 2133-2136.

Shinjo, R. and Kato, Y. (2000) Geochemical constraints on the origin of bimodal magmatism at the Okinawa Trough, an incipient back-arc basin. Lithos 54, 117-137.

Sholkovitz, E. R., Landing, W. M. and Lewis, B. L. (1994) Ocean particle chemistry: The fractionation of rare earth elements between suspended particles and seawater. Geochim. Cosmochim. Acta 58, 1567-1580.
Sverjensky, D. A. (1984) Eu redox equilibria in aqueous solution. Earth Planet. Sci. Lett. 67, 70-78.

Tachikawa, K., Jeandel, C. and Dupre, B. (1997) Distribution of rare earth elements and neodymium isotopes in settling particulate material of the tropical Atlantic Ocean (EUMELI site). Deep-Sea Res. 44, 1769-1792.

Tachikawa, K., Jeandel, C., Vangriesheim, A. and Dupre, B. (1999) Distribution of rare earth elements and neodymium isotopes in suspended particles of the tropical Atlantic Ocean (EUMELI site). Deep-Sea Res. 46, 733-755.

Taylor, S. R. and McLennan, S. M. (1985) An examination of the geochemical record preserved in sedimentary rocks. The Continental Crust: Its Composition and Evolution, Blackwell, Oxford, 312 pp.

Tsunogai, U., Toki, T., Nakayama, N., Gamo, T., Kato, H. and Kaneko, S. (2003) WHATS: a new multi-bottle gas-tight sampler for seafloor vent fluids. Chikyukagaku (Geochemistry) 37, 101-109 (in Japanese).

Von Damm, K. L., Edmond, J. M., Measures, C. I. and Grant, B. (1985) Chemistry of submarine hydrothermal solutions at Guaymas Basin, Gulf of California. Geochim. Cosmochim. Acta 49, 2221-2237.

Zhang, J. and Nozaki, Y. (1996) Rare earth elements and yttrium in seawater: ICP-MS determinations in the East Caroline, Coral Sea and South Fiji basins of the western South Pacific Ocean. Geochim. Cosmochim. Acta 60, 46314644.

Zhang, J. and Nozaki, Y. (1998) Behavior of rare earth elements in seawater at the ocean margin: A study along the slopes of the Sagami and Nankai Troughs near Japan. Geochim. Cosmochim. Acta 62, 1307-1317. 